\title{
Transition to Virtual Microscopy in Medical Undergraduate Pathology Education: First Experience of Turkey in Dokuz Eylül University Hospital
}

\author{
Tıp Fakültesi Mezuniyet Öncesi Patoloji Eğitiminde Sanal Mikroskopiye \\ Geçiş: Dokuz Eylül Üniversite Hastanesi'nde Türkiye'nin Illk Deneyimi
}

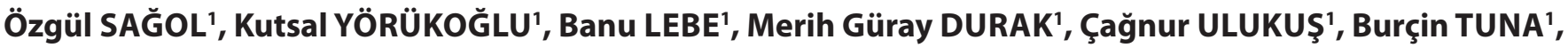 \\ Berna MUSAL ${ }^{2}$, Tülay CANDA ${ }^{1}$, Erdener ÖZER ${ }^{1}$
}

Department of 'Pathology and ${ }^{2}$ Medical Education, Dokuz Eylül University Faculty of Medicine, IZMIR, TURKEY

\begin{abstract}
Objective: Pathology education includes an important visual part supporting a wide range of theoretical knowledge. However, the use of traditional microscopes in pathology education has declined over the last decade and there is a lack of interest for microscopy. Virtual microscopy, which was first described in 1985 and has experienced a revolution since 2000, is an alternative technique to conventional microscopy, in which microscopic slides are scanned to form digital images and stored in the web. The aim of this study was to evaluate the use of virtual microscopy in practical pathology sessions and its effects on our students and undergraduate education at our faculty.
\end{abstract}

Material and Method: Second and third year medical students who were used to conventional microscopes were included in the study. The practical sessions were carried out via virtual slides and the effect of the new technique was investigated by a scale at the end of each session. Academic staff from the pathology department joined sessions to promote discussion and respond to questions. Student ratings were analysed statistically.

Results: The evaluation of the ratings showed that the students were easily adapted to the use of virtual microscopy. They found it user-friendly and thought that the opportunity of viewing slides at home was advantageous. Collaboration between students and interactive discussions was also improved with this technique.

Conclusion: It was concluded that the use of virtual microscopy could contribute to the pathology education of our students.

Key Words: Virtual systems, Pathology, Problem based learning, Microscope, Medical education

\section{ÖZ}

Amaç: Patoloji eğitimi, geniş teorik bilgiyi destekleyen önemli bir görsel kısım içerir. Ancak son dekatta patoloji eğitiminde geleneksel mikroskopların kullanımına ve mikroskopiye ilgi gittikçe azalmaktadır. İlk olarak 1985 yılında tanımlanan sanal mikroskopi 2000'lerden bu yana gelişim göstermiş ve mikroskopik görüntülerin taranarak internet ortamında dijital görüntüler halinde depolanabildiği, konvansiyonel mikroskopiye alternatif bir yöntem haline gelmiştir. Bu çalışmanın amacı sanal mikroskopinin patoloji pratiklerinde fakültemizde kullanımının, öğrenciler ve fakültemizdeki lisans eğitimi üzerindeki etkisinin araştırılmasıdır.

Gereç ve Yöntem: Bu çalışmaya konvansiyonel mikroskopiyi daha önce kullanmaya alışkın, ikinci ve üçüncü yıl tıp öğrencileri dahil edilmiştir. Pratik dersler sanal görüntülerle uygulanmış ve her ders sonunda yeni tekniğin etkisi ölçek formları ile test edilmiştir. Derslere, sorulara yanıt vermek ve tartışmayı yönlendirmek amacıyla patoloji bölümü öğretim üyeleri katılmışlardır. Öğrencilerin ölçeğe verdikleri puanlar istatistiksel olarak değerlendirilmiştir.

Bulgular: Ölçek sonuçlarının değerlendirilmesi sonucunda öğrencilerin patoloji eğitiminde sanal mikroskopi kullanımına kolaylıkla adapte olduğu gözlemlenmiştir. Öğrenciler yöntemi kullanımı kolay ve evden kesitleri inceleyebilmeyi avantajlı bulmuşlardır. Ayrıca bu yöntem ile öğrencilerin ortak çalışması ve derse interaktif katılımları artmıştır.

Sonuç: Fakültemizde sanal mikroskopi kullanımının öğrencilerin patoloji eğitimine ek katkı sağlayacağı sonucuna varılmıştır.

Anahtar Sözcükler: Sanal sistemler, Patoloji, Probleme dayalı öğretim, Mikroskopi
(Turk Patoloji Derg 2015, 31:175-180)

Received : 10.02.2015 Accepted : 13.08.2015
Correspondence: Özgül SAĞOL

Dokuz Eylül Üniversitesi Tip Fakültesi, Patoloji Anabilim Dalı,

İZMİ, TURKEY

E-mail: ozgul.sagol@deu.edu.tr Phone: + 902324123404 


\section{INTRODUCTION}

Pathology education, which is a highly visual subject, is partly based on histological examination of diseased tissues. This practical part is important because it helps students understand the basic concepts as well as the mechanisms of diseases. Analysing tissue and searching for clues of diagnosis improve the students' approach to the disease, simulating clinical examination of a patient (1). Additionally, the students can imagine how the tissue is processed and what the daily work of a pathologist looks like $(2,3)$.

The microscope has been the most widely used instrument in pathology education. However, some recent studies have demonstrated a decrease in the use of traditional microscopes in medical schools, mainly as a result of current developments in the curriculum as well as some disadvantages of the technique itself (4). The quality of educational microscopes used in many faculties is often poor and the cost of the new technology microscopes is quite high. Thus, adapting the laboratory to evolving technology and increasing the number of medical school students is costly. Maintenance of an adequate slide collection is also difficult and creates a huge increase in laboratory work as hundreds of slides are selected, cut, stained and sorted. Moreover, the slides have to be changed regularly because of fading of the dye or slide damage. Variability between sections in the slide collection often cause confusion among students and affects the success of teaching process. In addition, a large reserve of tissue is needed while preparing a slide set for the whole class. Cytological samples, small biopsies and special areas in biopsies such as transition of dysplastic epithelium to invasive cancer are generally difficult to reproduce in large numbers of consecutive slides and therefore difficult to demonstrate to all students $(3,4)$. To standardize sections and the representative areas that the students are supposed to see is not possible with light microscopy sections. Finding sufficient laboratory time for slide review during a busy curriculum is also a problem. The use of the microscopes is often limited to the working hours of the faculty, requiring the students to be physically at school for self study (5).

Medical students frequently complain about difficulties in finding lesions while examining histologic slides by microscopes. These difficulties mainly originate from lack of orientation of the organ and the lesion that they need to learn. Since very low power magnification that makes an overview easier is not available in student microscopes, getting oriented to the whole slide is quite difficult. Thus, there is usually need for demonstration on a projection screen in a classroom setting. Even after demonstration, students may hardly correlate what they see on the microscope with the demonstrated lesion. Unfortunately, being unable to put annotations on each slide other than crude dotting, limits students' proper orientation to the lesion (6).

There has been a change towards using microphotographs in practical sessions because of the mentioned difficulties. However, this has not been a satisfactory solution especially for the orientation problem. Virtual microscopy or digital slide technology, which serves as a simulator of microscopy, provides an effective solution for this problem. The experience of the medical schools that partially or completely integrated the virtual microscope technology into their histology and pathology curricula has previously been reported. Learning with this technique was accepted by students at a high rate in most of these studies (6-16). Experience with the integration of this technology to active learning curricula is more limited (17). Virtual microscopy has not only been reported to improve the student learning process, but it has also been shown in several studies to improve their collaboration skills, communication abilities and self-confidence (12). Due to the mentioned reasons, we have decided that transition to virtual microscopy is needed in our curriculum and have planned this study.

\section{MATERIALS and METHODS}

This project was carried out with two groups of students who were in their second and third year of medical education at Dokuz Eylul University Hospital. Problem-based learning is applied during the first three years at our institution. A total of 188 second and 163 third year students, who had already become adapted to individual single headed monocular microscopes (since they had practical histology sessions in their first year) participated in the study. Two practical sessions were selected from each second and third year curricula. The topics of the practical sessions were as follows:

1. Viral hepatitis (Second year, gastrointestinal system, nutrition and metabolism block )

2. Atherosclerosis (Second year, cardiovascular system block )

3. Neoplasia (Third year, neoplasia block)

4. Viral dermatosis (Third year, skin and locomotor system block)

The slides that were intended to be taught in these practical sessions were selected from pathology archives by the responsible instructor. Normal tissues were also selected in 


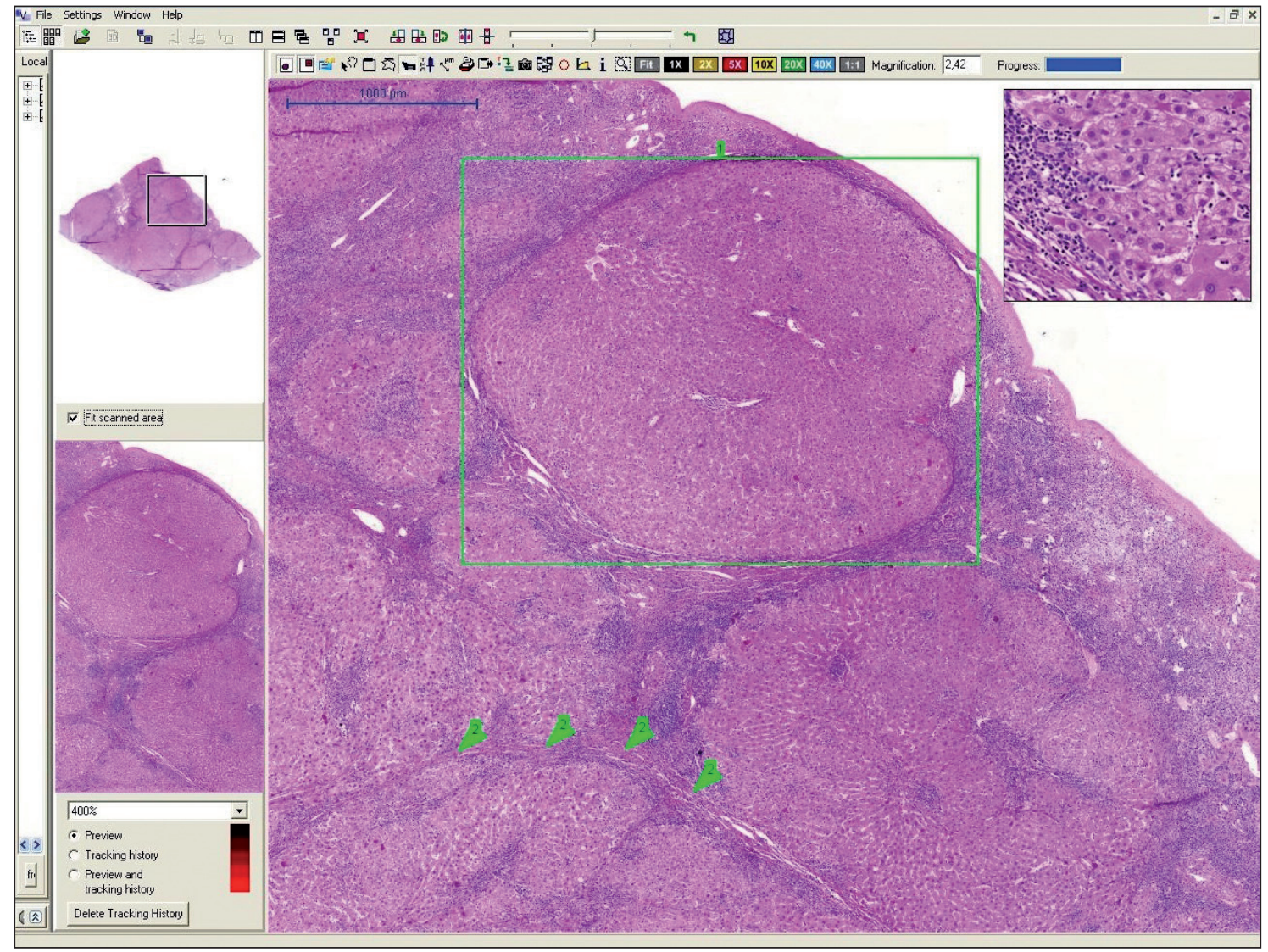

Figure 1: A virtual slide of a cirrhotic liver section, with annotations.

order to remind students the normal histology of the related organ. The slides were scanned with a slide scanner (Mirax Midi, 3DHistech, with a Hitachi 3CCD camera) with a 20X objective and the high resolution images were uploaded to the server. Annotations including squares, arrows or shapes with numbers, pointing to the microscopic features, were placed on each tissue. The slides were viewed with Mirax Viewer software that was downloaded for free from the web. All students had free access to the digital slides (Figure 1). They could access the slides at the http://194.27.56.209/ mirax web site from any computer with an internet connection. A tutor guide was prepared and given to all students before the practical session, describing how to access the digital slides and how to interpret the sections. Scientific knowledge about the disease, description of annotations, and the learning objectives were also included in these guides. The first practical session for second year medical students focused on the pathology of viral hepatitis and cirrhosis. The students were first given a detailed theoretical lecture on the elementary microscopic findings of chronic viral hepatitis and cirrhosis via a Powerpoint presentation, the day before the practical session. Other practical sessions were carried out the same way. The students were given information about the virtual microscopy technique and how they would use the Mirax Viewer program in the computer laboratory at the end of the first lecture in each class.

The computer laboratory included 80 computers with internet access and installed Mirax Viewer program in 3 rooms. At least one tutor in each laboratory supervised the learning process. Two students or more shared a computer when needed. The students were allowed to work in larger groups for interactive discussions. At the beginning of the practical session, the students were given a guide introducing the Mirax Viewer program, step by step. This guide also included the list of microscopic features they were supposed to learn during the session. The students were asked to match these microscopic findings in the list with annotation numbers on each slide. In the neoplasia practical session, a powerpoint presentation with clinical histories and macroscopic photographs were also downloaded to the desktops for students to view before working on the virtual images. Scales with 10 questions were distributed to students at the end of each session. The scale included ratings of the virtual slide sessions, from 1 to 5 ( 5: I Strongly agree, 4: I agree, 3: I have no idea, 2: I disagree, 3: I strongly disagree). In the scale used in this study, some questions allowed 
the students to make comparisons between traditional microscopes and virtual slides, as they had experience previously on how to use traditional microscopes in their histology sessions. Unfortunately, both techniques could not be used at the same time for the purpose of comparison because of the laboratory conditions and timing issues. A total of 248 students participated in the survey. The student ratings were analysed statistically by SPSS 15.0 software. The scale used in this study is given in Table I.

\section{RESULTS}

The results of the students ratings are given in Table II. The reliability analysis of the scale used in this study showed that the mean Cronbach Alpha value was 0.90. The students were well adapted to the virtual microscopy technique. They found it user-friendly, practical, easier to use and also found the opportunity to view slides at home advantageous. They appreciated the image quality. Most of them agreed that virtual slides could replace or be used in combination with traditional microscopes. They liked viewing slides in collaboration with their friends and this improved their understanding of the histopathology. They never complained about sharing their computers with one or two friends. Being able to view the normal histologic slides as well as the pathologic samples for comparison also contributed to their learning. In spite of the fact that they were able to discuss their findings with their friends, and the histopathology of the lesions were given as lectures before the practical sessions, they still requested the supervising of a tutor. The ability to view the slides at home did not decrease their attendance to practical sessions. They followed the instructions given as handouts and

Table I: Scale used to evaluate the students' satisfaction . (5: I Strongly agree, 4: I agree, 3: I have no idea, 2: I disagree, 1: I strongly disagree)

1- Virtual microscopy is more practical and easier to use than conventional microscopy.

2- The Mirax Viewer software used in this lesson is user-friendly.

3- Virtual microscopy is less time consuming than conventional microscopy.

4- The image quality is as good as conventional microscopy.

5- I can discuss the microscopic findings with my friends and ask my questions to the tutors easier when compared with conventional microscopy.

6- I find it advantageous to be able to look at the virtual slides at home as well.

7- Virtual microscopy technology can replace conventional microscopy in pathology education.

8- Virtual microscopy should be used in combinaton with conventional microscopy in pathology education.

9- It is fun to use virtual microscopy in pathology education.

10 -Please write any additional feedback related to the contribution of virtual microscopy to pathology education.

Table II: Student ratings as percentage. (5: I Strongly agree, 4: I agree, 3: I have no idea, 2: I disagree, 1: I strongly disagree)

\begin{tabular}{|l|c|c|c|c|c|}
\hline Question & \multicolumn{5}{|c|}{ Student ratings as percentage (Total: 248 students) } \\
\hline & $\mathbf{1}$ & $\mathbf{2}$ & $\mathbf{3}$ & $\mathbf{4}$ & $\mathbf{5}$ \\
\hline 1- Practical/easier & 4.4 & 1.2 & 2.4 & 28.2 & 63.7 \\
\hline 2- Software is user-friendly & 3.6 & 4.0 & 2.0 & 33.9 & 56.5 \\
\hline 3- Less time consuming & 2.8 & 6.0 & 6.0 & 29.4 & 55.6 \\
\hline 4- Good image quality & 1.6 & 0.8 & 1.2 & 21.4 & 75.0 \\
\hline 5- Interactive discussion advantage & 6.5 & 8.5 & 4.1 & 24.8 & 56.1 \\
\hline 6- Accessibility at home & 2.0 & 1.2 & 4.0 & 23.8 & 68.9 \\
\hline 7- Can replace microscope & 4.9 & 13.1 & 8.6 & 26.2 & 47.1 \\
\hline 8- Should be used in combination & 5.3 & 12.7 & 10.7 & 28.9 & 41.4 \\
\hline 9- It's fun & 4.9 & 7.4 & 7.8 & 30.5 & 49.4 \\
\hline
\end{tabular}


tried to match the lesions shown by annotations with the given pathological findings in the handouts. The matching exercise improved group discussions at the end of the lesson as the students tried to compare their results with each other and with the tutors. At the end of each block, the students attended practical exams that were integrated with other disciplines such as microbiology, parasitology and pharmacology. In these exams, microphotographs taken from the virtual slides that had been viewed in the practical sessions were used in pathology questions. The comparison between the grades of previous and current exams could not be made definitely as the components of the exams differed considerably.

\section{DISCUSSION}

Virtual microscopy, also known as digital slide technology (DST) or whole slide imaging, is a way of creating dynamic images from glass slide specimens, which are viewed and manipulated by using computer-based technology, closely mimicking traditional light microscopy $(12,13,18)$. While examining the virtual slides, the user can change the field of view by panning in the $\mathrm{x}-\mathrm{y}$ axis and zooming from one magnification to another, just as viewing a glass slide with a traditional optical microscope. Development of digitalized slides had begun in 1985, when multiple microscopic views (digital tiles) had been taken via motorized microscopic stages and virtual slides had been created by a digital montage. Then in the late 1990s, virtual slide preparation with a slide scanner was described. Integration with annotations, which increased the educational value of virtual slides was developed in 2001 (4).

Virtual microscopy has been used in many fields of pathology. Recently, some institutions have even integrated this technology to their daily diagnostic practice. Actually, the majority of the literature reports no significant difference in diagnostic abilities with virtual slides in comparison to glass slides $(12,14)$. Others use virtual slides for research, consultation, teaching and other academic purposes. Currently there is increasing evidence in the literature that many medical faculties prefer using virtual slides in their pathology education.

In the early 1990s, pathology education had mostly relied on lectures and laboratories built on traditional microscopes. However, the recent curricular reform with the integrated approach has decreased the time allocated to pathology and other basic sciences because of the need to adapt clinical issues in the first two years of medical education. Problembased or self-directed study has replaced the didactic teaching with lectures and laboratories. There is a tendency to believe that practicing physicians other than pathologists do not need to know how to use a microscope. The rate of glass slide use in teaching histopathology was reported to be as high as $85 \%$ in 1997 by Kumar et al. In a survey presented at Association of Pathology Chairs in 2007 in the US, only $45 \%$ of medical schools had studied histopathology in their curricula and among these only $18 \%$ had used glass slides in teaching (4).

Problem-based learning has been used in the first three years at Dokuz Eylul University Faculty of Medicine since 1996. Problem-based learning sessions have been integrated with theoretical lectures and practical lessons as well as independent study times for students. As a part of this active model of learning, practical pathology sessions on some selected important topics were integrated within the curriculum. However, the practical sessions had to be integrated with other disciplines such as microbiology and parasitology because of the limited partition of pathology among our integrated curriculum. These integrated practical sessions required large laboratories other than microscopy laboratories.

The use of glass slides had nearly been given up at Dokuz Eylul University in the first 3 years of medical education with transition to problem-based learning in 1996. Since then, histopathology had been taught by using digital microphotographs used in posters or Powerpoint presentations, prepared for the students' self-study during practical sessions. With that method, exploring a section, finding normal and pathologic structures independently, as well as discovering relationships within the same tissue was impossible. In spite of the labels on the photographs, the students were not able to orientate the morphologic findings they saw on the pictures. The tutors generally had poor feedback at the end of each practical session. Additionally, there was a need for more residents and instructors supervising, because the students required detailed explanations to understand the microscopic findings on the microphotographs. Thus, the practical sessions became lectures instead of an active learning experience.

As a result of the decision of transition to virtual slides in our faculty, many advantages of virtual slides compared to glass slides have been reported. First of all, the virtual slides can be viewed anytime and anywhere a computer and an Internet connection is available. The quality of images is standard and there is no need for focusing, proper condenser adjustment, and lighting that cannot be performed easily by the students on traditional microscopes. Technical competence in viewing is easier to manage when compared to traditional microscopes. The very low power overview 
allows students to better recognize relationships of normal tissues to pathologic lesions. A thumbnail and location box in the viewer program allows students to remain oriented to the whole slide while viewing at high magnification. In addition, labeling the tissue with annotations, integrating descriptions, case scenarios, and gross and radiological images is also possible and improves understanding. The storage of the virtual slides is easier, when enough server space is provided $(4,5)$. Computer screen allows student collaboration and group discussions, and these have been confirmed by our own students as well.

The improvement of learning while practicing specific skills by the use of simulation-based tools such as phlebotomy or resuscitation models is the main purpose in medical education (19). Similar to these simulation-based techniques used in medical education, virtual slides have already taken their place within the learning process in pathology. For the first time in Turkey, we experienced an improvement in pathology education in our institution with this technique. Therefore, we think that this technology is applicable to medical school curricula, which will otherwise turn out to be completely theoretical and devoid of visuality while teaching basic aspects of medicine.

\section{SOURCE OF FUNDING}

This research was supported by Dokuz Eylül University Research Foundation Grant. Grant Number: 2008. KB. SAG. 018

\section{CONFLICT OF INTEREST}

The authors declare no conflict of interests.

\section{REFERENCES}

1. Braun MW, Kearns KD. Improved learning efficiency and increased student collaboration through use of virtual microscopy in the teaching of human pathology. Anat Sci Educ. 2008;1:240-6.

2. Coleman R. Can histology and pathology be taught without microscopes? The advantages and disadvantages of virtual histology. Acta Histochemica. 2009;111:1-4.

3. Merk M, Knuechel R, Perez-Bouza A. Web-based virtual microscopy at the RWTH Aachen University: Didactic concept, methods and analysis of acceptance by the students. Ann Anat. 2010;192:383-7.

4. Dee FR. Virtual microscopy in pathology education. Hum Pathol. 2009;40:1112-21.
5. Foster K. Medical education in the digital age: Digital whole slide imaging as a learning tool. J Pathol Inform. 2010;1. pii: 14.

6. Kumar KR, Velan GM, Korell SO, Kandara M, Dee FR, Wake D. Virtual microscopy for learning and assessment in pathology. J Pathol. 2004;204:613-8.

7. Heidger PM, Dee FR, Consoer D, Leaven T, Duncan J, Kreiter C. Integrated approach to teaching and testing in histology with real and virtual imaging. Anat Rec. 2002;269:107-12.

8. Blake C, Lavoie HA, Millette CF. Teaching medical histology at the University of South Carolina School of Medicine: Transition to virtual slides and virtual microscopes. Anat Rec B New Anat. 2003;275:196-206.

9. Krippendorf BB, Lough J. Complete and rapid switch from light microscopy to virtual microscopy for teaching medical histology. Anat Rec B New Anat. 2005;285:19-25.

10. Kim MH, Park Y, Seo D, Lim YJ, Kim D, Kim CW, Kim WH. Virtual microscopy as a practical alternative to conventional microscopy in pathology education. Basic Appl Pathol. 2008;1: 46-8.

11. McBride JM, Prayson RA. Development of a synergistic casebased microanatomy curriculum. Anat Sci Educ. 2008;1:102-5.

12. Weinstein RS. Innovations in medical imaging and virtual microscopy. Hum Pathol. 2005;36;317-9.

13. Scoville SA, Buskirk TD. Traditional and virtual microscopy compared experimentally in a classroom setting. Clin Anat. 2007;20:565-70.

14. Kumar RK, Freeman B, Velan GM, De Permentier PJ. Integrating histology and histopathology teaching in practical classes using virtual slides. Anat Rec B New Anat. 2006;289:128-33.

15. Hamilton PW, Wang Y, McCullough SJ. Virtual microscopy and digital pathology in training and education. APMIS. 2012;120:305-15.

16. Dee FR, Meyerholz DK. Teaching medical pathology in the twenty-first century: Virtual microscopy applications. J Vet Med Educ. 2007;34:431-6.

17. Bloodgood RA. Active learning: A small group histology laboratory exercise in a whole class setting utilizing virtual slides and peer education. Anat Sci Educ. 2012;5:367-73.

18. Weinstein RS, Graham AR, Richter LC, Barker GP, Krupinski EA, Lopez AM, Erps KA, Bhattacharyya AK, Yagi Y, Gilbertson JR. Overview of telepathology, virtual microscopy, and whole slide imaging: Prospects for the future. Hum Pathol. 2009;40:1057-69.

19. Nelson D, Ziv A, Bandali KS. Going glass to digital: Virtual microscopy as a simulation-based revolution in pathology and laboratory science. J Clin Pathol. 2012;65:877-81. 